\title{
NEGARA HUKUM (RECHTSTAAT) DALAM PERSPEKTIF ISLAM
}

\author{
Ahmad Subekti \\ FAI Unisma Malang \\ e-mail: ahmad.subekti@unisma.ac.id
}

Diterima: 14 - 05 - 2019 | Direvisi: 14-06 - 2019 | Disetujui: 14 - 06 - 2019

(C) 2019 Program Studi Ahwal Syakhshiyyah Fakultas Agama Islam Universitas Islam Malang

\begin{abstract}
Abstrak
Indonesia adalah Negara Hukum (Rechtstaat), oleh karena itu ada konsekuensi logis dan moral yang harus dijalankan, baik oleh aparat / penguasa sebagai penegak hukum maupun rakyat sebagai warga Negara yang harus taat pada aturan hukum. Adanya kelompok terterntu yang ingin merubah system negara Indonesia dengan system yang mereka fahami dengan cara kekerasan mencederai sikap saling menghargai dan sikap keadilan masyarakat Indonesia yang bermacammacam. Metode penelitian kulaitatif digunakan dalam penelitian pustaka ini. Dengan peenggunaan konten analisis dalam membahas temuan yang menjawah permasalahan. Dalam perspektif Islam, sistem dan bentuk Negara bisa bermacammacam dan berbeda-beda, tetapi maksud dan tujuan pembentukan Negara adalah sama, yaitu terwujudnya Negara dan pemerintahan yang adil, damai, dan sejahtera (Darussalam). Hal ini bisa kita lihat dalam Negara dan pemerintahan di Madinah yang dipimpin oleh Muhammad Rasulullah SAW. Untuk mewujudkan cita-cita Negara "Darussalam" tersebut, maka dibuatlah sistem dan tata kelola Negara hukum yang didasarkan pada Nash Al Qur'an, As - Sunnah, atau dengan cara ijtihad, apabila kemaslahatan umum mengharuskan demikian, sebagaimana yang dijelaskan dalam kaidah hukum Islam (Qaidah Fiqhiyah) :"Tasharuf(tindakan) Imam terhadap rakyat harus dihubungkan dengan kemaslahatan".
\end{abstract}

Kata kunci: Negara, prespektif, Hukum, dan Islam

This work is licensed under Creative Commons Attribution Non Commercial 4.0 International License Available online on: http://riset.unisma.ac.id/index.php/fai/index 


\section{A. PENDAHULUAN}

Negara Indonesia adalah negara multicultural yang penyelenggaraan negara harus didasarkan kesepakatan bersama. Dengan kesepakatan Bersama, masing masing bagian yang berbeda dapat dihargai kontribusinya dan kepercayaannya. Aturan aturan adat yang sudah ada dan melekat di masyarakat tetap bias berjalan tanpa ada diskriminsasi.

Akhri akhir ini muncul kelompok-kelompok yang menginginkan negara Indonesia diikutkan system pemerintahan satu kelompok saja. Hal ini karena kelompok tersebut terkena faham dari luar negeri yang sedang disebarkan secara luas. Dan kelompok tersebut secara kebetulan beragama Islam. System negara yang diinginkan mereka fahami sibagai system islami, padahal beberapa cendekiawan menyatakan Islam tidak memberikan konsep negara bersistem Islami. Kasus yang menjadi perhatian juga adalah mereka dalam menyuarakan pemahaman mereka tidak hanya menggunakan tindakan yang damai tetapi juga dengan kekerasan. Hal inilah perlunya mengkaji bagaimana Islam dalam memberikan bimbingan untuk sebuah negara.

\section{B. Metode}

Adapun metode kajian penelitian kualitatif ini sifatnya lebih ke arah metode kajian atas gagasan konseptual sedang data-data yang dikumpulkan dan yang akan dianalisis bertumpu pada ketersediaan sumber data di perpustakaan (Library Research) Sedang untuk teknik nalisis data yang digunkan dalam kajian ini adalah teknik Analisis isi (content analysis) yakni sebuah teknik yang secara komprehensip berusaha menggali beragam keterangan dari pesan atau informasi yang disajikan dalam wujud lambang atau simbol tertentu yang terdokumentasi atau dapat didokumentasikan. Sedang sumber data penelitian ini diperoleh dari beragam sumber yang bersifat kekinian dengan tidak meninggalkan referensi klasik

JAS: Volume 1 Nomor 1, 2019 


\section{Hasil dan Pembahasan}

Prinsip-Prinsip Negara Hukum Menurut Islam

\section{Kekuasaan Sebagai Amanah (Al - Amanah)}

Kekuasaan adalah suatu karunia atau nikmat Allah yang merupakan suatu amanah kepada manusia untuk dipelihara dan dilaksanakan dengan sebaik-baiknya sesuai dengan prinsip-prinsip dasar yang telah ditetapkan dalam Al Qur'an dan dicontohkan oleh Sunnah Rasulullah. Kekuasaan itu kelak harus dipertanggungjawabkan kepada Allah, (M. Natsir, 2001: 22).

Sebaliknya, kalau kekuasaan itu diterapkan dengan cara yang menyimpang atau bertentangan dengan prinsip-prinsip dasar dalam Al Qur'an dan Sunnah Rasul, maka akan hilanglah makna hakiki kekuasaan itu, dan dalam keadaan seperti ini, kekuasaan bukan lagi merupakan karunia atau nikmat Allah, melainkan akan menjadi bencana dan laknat Allah, karena ia dianggap berkhianat terhadap amanah yang telah diberikan kepadanya.

Penyampaian amanah dalam kontekst kekuasaan mengandung suatu implikasi bahwa ada larangan bagi pemegang amanah itu untuk melakukan suatu "abuse" atau penyalahgunaan kekuasaan yang ia pegang. Apapun bentuk penyalahgunaan terhadap kekuasaan itu dalam Islam tidak dapat dibenarkan.

Allah SWT berfirman : "Sesungguhnya Allah menyuruh kamu menyampaikan amanat kepada yang berhak menerimanya, dan menyuruh kamu apabila menetapkan hukum diantara manusia supaya kamu menetapkannya dengan adil”. (QS. An-Nisa 158)

Dan sabda Nabi Muhammad SAW : “Setiap kamu adalah pemimpin dan setiap pemimpin itu bertanggungjawab atas yang dipimpinnya. Seorang Imam yang menjadi pemimpin rakyat bertanggungjawab terhadap rakyatnya" (HR. Bukhari dan Muslim)

\section{Prinsip Musyawarah (Asy - Syura)}

Musyawarah dapat diartikan sebagai suatu forum tukar menukar pikiran, gagasan ataupun ide, termasuk saran-saran yang diajukan dalam JAS: Volume 1 Nomor 1, 2019 
memecahkan sesuatu masalah sebelum tiba pada suatu pengambilan keputusan. Di lihat dari sudut kenegaraan, maka musyawarah adalah suatu prinsip konstitusional yang wajib dilaksanakan dalam suatu pemerintahan dengan tujuan untuk mencegah lahirnya keputusan yang merugikan kepentingan umum atau rakyat. (A. Ubaidillah dan Abdul Rozak, 2006: 57) Sebagai suatu prinsip konstitusional, maka dalam Islam musyawarah berfungsi sebagai "lem" atau pencegah kekuasaan yang absolute dari seorang penguasa atau kepala Negara. Menurut Al Mandudi, prinsip musyawarah merupakan cara yang efektif untuk membatasi kekuasaan eksekutif dan menutup celah bagi kemunculan dictator sebagai penguasa. Melalui musyawarah setiap masalah yang menyangkut kepentingan umum dan kepentingan rakyat dapat ditemukan suatu jalan keluar yang sebaik-baiknya setelah semua pihak mengemukakan pandangan dan pikiran mereka yang wajib didengar oleh pemegang kekuasaan Negara supaya ia dalam membuat suatu keputusan dapat mencerminkan pertimbangan-pertimbangan yang obyektif dan bijaksana untuk kepentingan umum. Suatu musyawarah dapat diakhiri dengan kebulatan pendapat atau kesepakatan bersama (konsensus) yang dalam hukum Islam lazim disebut Ijma’.

Pada masa kini musyawarah dapat dilaksanakan melalui suatu lembaga pemerintahan yang disebut dewan perwakilan atau apapun namanya yang sesuai dengan kebutuhan pada suatu waktu dan tempat. Aplikasi musyawarah termasuk dalam bidang atau lingkup wilayah Ijtihad manusia. Bagaimana bentuk dan cara musyawarah yang terbaik menurut suatu ukuran masa dan tempat, maka bentuk dan cara itulah yang digunakan. Baik Al Qur'an maupun As Sunnah sama sekali tidak menentukan hal ini. Ini mengandung hikmah yang besar bagi manusia. Artinya, musyawarah sebagai suatu prinsip konstitusional yang digariskan dalam Al Qur'an dan diteladankan melalui tradisi Nabi SAW

JAS: Volume 1 Nomor 1, 2019 
tidak perlu berubah. Namun aplikasi dan pelaksanaannya selalu dapat mengalami perubahan sesuai dengan perkembangan dan kemajuan masyarakat. Institusi-institusi politik dan Negara dalam sejarah manusia selalu mengalami perkembangan dan perubahan. Maka aplikasi musyawarah dalam suatu Negara menurut Islam boleh mengikuti bentuk dan cara lembagalembaga politik dan Negara yang selalu berubah dan berkembang itu sejauh tidak bertentangan atau menyimpang dari Jiwa Al Qur'an dan tradisi Nabi SAW.

Dalam tradisi Islam, suatu hal penting yang perlu diperhatikan dalam prinsip musyawarah ini ialah bahwa dari segi hukum Islam manusia dibenarkan melakukan musyawarah hanya dalam hal-hal yang ma'ruf atau kebaikan.

Karena itu musyawarah dilarang untuk digunakan dalam hal-hal yang munkar. Misalnya parlemen mau membuat undang-undang perjudian dan lain-lainnya yang sejenis, maka lembaga ini tidak dibenarkan menggunakan prinsip musyawarah untuk maksud itu, dan produk parlemen yang diproses dengan cara seperti ini menjadi tidak sah dan batal demi hukum. Dengan demikian ia tidak mempunyai kekuatan mengikat terhadap rakyat. Dengan kata lain pelaksanaan prinsip musyawarah harus sejalan dengan salah satu doktrin pokok dalam Islam, yaitu : "amar ma'ruf nahi munkar". Doktrin seperti ini tidak dijumpai dalam demokrasi Barat. Dan hal ini dapat disebut sebagai segi lain dari keunggulan prinsip musyawarah dalam Islam.

Al Qur'an mengisyaratkan bahwa untuk mengatasi setiap persoalan yang menyangkut masyarakat atau kepentingan umum, maka jalan musyawarah harus dilakukan sebagaimana yang diperintahkan Allah dalam firmanNya :

“..... dan bermusyawarahlah engkai wahai Muhammad dengan mereka dalam setiap urusan kemasyarakatan....." (Qs Ali Imran:159)

Oleh karena itu, sesuai dengan firman Allah SWT diatas, maka umat Islam wajib bermusyawarah dalam memecahkan setiap masalah kenegaraan. Kewajiban ini terutama dibebankan kepada setiap penyelenggara kekuasaan Negara dalam melaksanakan kekuasaannya tersebut. 


\section{Prinsip Keadilan (Al-'Adalah)}

Ajaran Islam mewajibkan penegakan keadilan baik terhadap diri sendiri, keluarga, tetangga, bahkan terhadap musuh sekalipun kita wajib bertindak adil. lain:

Banyak ayat-ayat Al Qur'an yang berbicara tentang keadilan, antara

"Dan janganlah sekali-kali kebencianmu terhadap suatu kaum mendorong kamu untuk berlaku tidak adil. Berlaku adillah, karena berlaku adil itu lebih dekat kepada taqwa". (Qs. Al Maidah :8)

"Wahai orang-orang yang beriman, jadilah kamu orang-orang yang menegakkan keadilan, menjadi saksi bagi Allah walaupun terhadap dirimu sendiri, terhadap ibu bapakmu, atau terhadap kaum kerabatmu”. (Qs. An-Nisa : 135)

"Sesungguhnya Allah menyuruh kamu berlaku adil dan berbuat kebajikan, memberi kepada kaum kerabat, dan Allah melarang perbuatan keji, kemungkaran dan permusuhan". (Qs. An - Nahl : 90)

Ayat-ayat diatas, mengisyaratkan agar kebencian dan kecintaan yang berlebihan tidak menyebabkan ketidakadilan.

Sedangkan prinsip keadilan apabila dikaitkan dengan Negara, maka ia harus selalu dilihat dari segi fungsi kekuasaan Negara. Fungsi itu mencakup tiga kewajiban pokok bagi penyelenggara Negara atau suatu pemerintahan sebagai pemegang kekuasaan yaitu :

Pertama, kewajiban menerapkan kekuasaan Negara dengan adil, jujur, dan bijaksana. Seluruh rakyat tanpa kecuali harus dapat merasakan "nikmat" keadilan yang timbul dari kekuasaan Negara misalnya, implementasi kekuasaan Negara dalam bidang politik dan pemerintahan. Semua rakyat harus dapat memperoleh hak-haknya secara adil tanpa sesuatu diskriminasi.

Kedua, Kewajiban menerapkan kekuasaan kehakiman dengan seadiladilnya. Hukum harus ditegakkan sebagaimana mestinya. Hukum berlaku bagi siapa saja, tanpa memandang kedudukan, sehingga tidak ada istilah tebang pilih, hukum tumpul ke atas, tajam ke bawah, dan lain-lain.

Ketiga, kewajiban penyelenggaraan Negara untuk mewujudkan suatu tujuan masyarakat yang adil, makmur, dan sejahtera di bawah keridhaan Allah SWT. Hal ini berkaitan dengan keadilan dan kesejahteraan sosial. Hukum

JAS: Volume 1 Nomor 1, 2019 
Islam sudah menetapkan beberapa lembaga sosial untuk mencapai tujuan itu. Misalnya zakat, yang merupakan suatu lembaga sosial yang mewajibkan bagi para hartawan atau golongan mampu. Zakat adalah hak setiap orang yang secara ekonomis memerlukannya. Ia merupakan perwujudan rasa solidaritas sosial dalam masyarakat Islam.

Prinsip keadilan dalam Islam, juga mengandung suatu konsep yang bernilai tinggi. Ia tidak identik dengan keadilan yang diciptakan oleh manusia. Keadilan buatan manusia dengan doktrin humanismenya telah mengasingkan nilai-nilai transcendental dan terlalu mengagungkan manusia sebagai individu, sehingga manusia menjadi titik sentral.

Sebaliknya, konsep keadilan dalam Islam menempatkan manusia pada kedudukan yang wajar, baik sebagai individu maupun sebagai suatu masyarakat. Manusia bukan merupakan titik sentral, melainkan ia adalah "hamba Allah" yang nilainya ditentukan oleh hubungannya dengan Allah dan dengan sesama manusia sendiri (hablun min Allah wa hablun min al nas).

Dalam doktrin Islam, hanya Allah yang menempati posisi sentral. Karena itu keadilan dalam humanisme Islam selalu bersifat teosentrik, artinya bertumpu dan berpusat kepada Allah Tuhan Yang Maha Adil dan Maha Kuasa. Dengan demikian konsep keadilan dalam Islam memiliki kelebihan yang tidak dijumpai dalam konsep-konsep keadilan versi manusia.

\section{Prinsip Persamaan (Al Musawah)}

Prinsip persamaan dalam Islam mengandung aspek yang luas. Ia mencakup persamaan dalam segala bidang kehidupan. Persamaan itu meliputi bidang hukum, politik, ekonomi, sosial, dan lain-lain. Persamaan dalam bidang hukum memberikan jaminan akan perlakuan dan perlindungan hukum yang sama terhadap semua orang tanpa memandang kedudukannya, apakah ia dari kalangan rakyat biasa atau dari kelompok elit. Prinsip ini telah ditegakkan oleh Nabi Muhammad SAW sebagai kepala Negara di Madinah, ketika ada sementara pihak yang menginginkan dispensasi karena tersangka berasal dari kelompok elit.

Nabi SAW bersabda: "Demi Allah, seandainya Fatimah Putriku mencuri tetap akan kupotong tangannya." (HR Abu Daud dan Nasa'i).

Hadits ini menunjukkan bahwa hukum harus di laksanakan terhadap siapa saja, tanpa memandang latar belakang keturunan atau kedudukannya.

Contoh yang lain adalah bahwa dalam sejarah Islam, tidak sedikit dari kalangan yang bukan elit menduduki jabatan-jabatan umum. Beberapa nama JAS: Volume 1 Nomor 1, 2019 
yang tadinya dikenal sebagai hamba sahaya, dalam masa pemerintahan Islam mereka menduduki jabatan penting, misalnya Zaid bin Haritsah pernah menjabat sebagai panglima, dan Ijasamah, putranya, pernah menjabat sebagai gubernur. Pengalaman dalam sejarah Islam itu dapat dikatakan merupakan fakta atau kenyataan yang memperkuat pendirian bahwa dalam Islam manusia memiliki posisi yang sama.

Dalam doktrin Islam, prinsip persamaan kecuali merupakan salah satu pilar hukum, ia juga megandung ajaran moral yang transcendental. Dalam ajaran moral yang transedental, kebenaran adalah kebenaran. Karena itu orang tidak mungkin melakkan tawar menawar atau kompromi tentang kebenaran.

Suatu peristiwa yang sangat menarik dalam konteks ini pernah dialami oleh salahudin al ayyubi, seorang panglima Islam yang terkenal dalam Perang Salib dan berhasil memenangkan peperangan itu. Dalam kedudukannya sebagai Kepala Negara, ia pernah dimohon oleh seorang pejabat tingginya supaya memberikan "jasa baik" atau "kebijaksanaan" hukum dalam kasus seorang yang telah melakukan tindak pidana penipuan. Permohonan itu ditolaknya dengan argumentasinya yang sangat kuat sebagaimana direkam oleh Muhammad Rasyid Ridha. ${ }^{3}$

"Tidak ada tindakan atau kebijaksanaan yang bisa diharapkan, baik untuk kepentingan anda maupun untuk kepentingan orang-orang Islam lain, dalam masalah hukum seorang hakim akan memutuskan hukum mencakup semuanya, baik orang penting maupun orang awam, sedangkan segala perintah dan segala larangannya mengikat dan harus ditaati. Aku hanyalah seorang hamba hukum dan pengawalnya. Kebenaran dan keadilanlah yang akan memutuskan hukum, entah menguntungkan anda atau merugikan anda....".

Peristiwa diatas memperlihatkan dengan jelas bahwa prinsip persamaan di hadapan hukum dalam Islam wajib ditegakkan. Sikap Salahudin Al Ayyubi dalam menghadapi kasus tersebut merupakan salah satu pencerminan dari watak seorang kepala Negara yang dengan sungguhsungguh dan penuh tanggung jawab melaksanakan prinsip-prinsip Negara hukum menurut AlQur'an dan Sunnah Rasul. antara lain :

Simbol persamaan kemanusiaan ini diisyaratkan dalam Al Qur'an,

"Hai manusia, sesungguhnya Kami menciptakan kamu dari seorang lakilaki dan seorang perempuan dan menjadikan kamu berbangsa-bangsa dan bersuku-suku supaya kamu saling kenal mengenal. Sesungguhnya orang yang

JAS: Volume 1 Nomor 1, 2019 
paling mulia disisi Allah ialah orang-orang yang paling bertaqwa diantara kamu. Sesungguhnya Allah Maha Mengetahui dan Maha Mengenal". (QS Al Hujurat:13).

"Dan barang siapa mengerjakan amal kebaikan, baik laki-laki maupun perempuan sedang dia beriman, maka mereka itu akan masuk ke dalam surge dan mereka tidak dizalimi sedikit pun". (QS An-Nisa : 124).

"Maka Tuhan mereka memperkenankan permohonannya (dengan berfirman), sesungguhnya Aku tidak menyia-nyiakan amal orang yang beramal diantara kamu baik laki-laki maupun perempuan, (karena) sebagian kamu adalah (keturunan) darisebagian yang lain ....." (QS Ali Imran :195)

"Barang siapa mengerjaka kebajikan, baik laki-laki maupun perempuan dalam keadaan beriman, maka pasti akan Kami berikan kepadanya kehidupan yang baik, dan akan Kami beri balasan dengan pahala yang lebih baik dari apa yang telah mereka kerjakan". (QS An-Nahl : 97).

\section{Prinsip Kemerdekaan (Al - Huriyah)}

Kemerdekaan yang sesungguhnya dimulai dari pembebasan diri dari pengaruh hawa nafsu serta mengendalikannya di bawah bimbibingan keimanan dan akal sehat. Dengan demikian, kebebasan bukanlah kebebasan mutlak, akan tetapi kebebasan dan kemerdekaan yang bertanggungjawab terhadap Allah serta terhadap keselamatan dan kemaslahatan hidup manusia di muka bumi ini.

Ada beberapa prinsip kemerdekaan dalam Islam yang ditegaskan Allah dalam Al Qur'an, yaitu antara lain :

1. Kebebasan Beragama

Islam memberikan kebebasan kepada manusia untuk menganut agama yang dia kehendaki dan tidak seorangpun bisa memaksa, baik secara halus, apalagi dengan tindak kekerasan untuk berpindah agama.

Di dalam Al Qur'an, ada serangkaian ayat-ayat yang menegaskan bahwa setiap manusia memiliki kebebasan penuh untuk beragama. Sebagaimana bunyi firman Allah SWT :

"Tidak ada paksaan untuk memeluk agama islam, sesungguhnya telah jelas jalan yang benar dari pada jalan yang sesat. Karena itu barang siapa yang ingkar kepada Thaghut (yaitu syaitan dan apa saja yang disembah selain Allah) dan beriman kepada Allah, maka sesungguhnya ia telah berpegang kepada tali yang amat kuat yang tidak akan putus. Dan Allah Maha Mendengar Lagi Maha Mengetahui. (QS. Al Baqarah : 256).

JAS: Volume 1 Nomor 1, 2019 
Dari ayat diatas dapat ditarik kesimpulan bahwa manusia dilarang memaksa orang lain untuk menganut agama Islam. Al Qur'an telah menjelaskan bahwa kebenaran dan kesesatan sudah jelas perbedaannya. Apabila ia memilih atau menganut agama Islam, maka ia dinyatakan telah memilih jalan kebenaran. Sebaliknya, apabila manusia mengikuti taghut maka ia dinyatakan telah memilih jalan yang sesat.

\section{Kebebasan berpikir dan menyatakan pendapat}

Kebebasan berpikir merupakan salah satu fitrah manusia atau watak aslinya. Termasuk dalam pengertian ini adalah kebebasan manusia menggunakan pikirannya untuk kepentingan ilmu pengetahuan. Dalam sejarah dijumpai suatu kenyataan bahwa hanyalah Islam yang sejak semula lahirnya mendorong setiap manusia untuk menuntut ilmu dan menggunakan pikirannya untuk kepentingan pengembangan ilmu pengetahuan.

Dalam ajaran Islam, kebebasan berpikir sangat dihargai, sehingga orang yang berani menyatakan pendapatnya yang benar dihadapan penguasa yang otoriter atau zalim, dinilai sebagai suatu perjuangan yang paling mulia.

Kebebasan berpikir juga mengandung maksud dan tujuan, agar manusia terbebas dari keraguan dan taqlid buta, bahkan Islam mendorong untuk bebas memikirkan tentang alam semesta, tentang dirinya, dan tentang apa yang dilihat dan didengar. Sebagaimana bunyi firman Allah SWT :

"Dan mengapa mereka tidak memikirkan tentang kejadian diri mereka? Allah tidak menjadikan langit dan bumi dan apa yang ada diantara keduanya melainkan dengan tujuan yang benar dan waktu yang ditentukan. Dan sesungguhnya kebanyakan diantara manusia benar-benar ingkar akan pertemuan dengan Tuhannya". (QS Ar-Rum : 8)

“... Dan orang-orang yang mendalam ilmunya berkata : "Kami beriman kepada ayat-ayat yang mutasyabihat, semuanya itu dari sisi Tuhan kami". Dan tidak dapat mengambil pelajaran dari padanya melainkan orang-orang yang berakal." (QS Ali Imran:7)

"Dan apabila dikatakan kepada mereka : Ikutilah apa yang telah diturunkan Allah," mereka menjawab: "Tidak, tetapi kami hanya mengikuti apa yang telah kami dapati dari perbuatan nenek moyang kami." Apakah mereka akan mengikuti juga, walaupun nenek moyang mereka itu tidak mengetahui suatu apapun, dan tidak mendapat petunjuk?" (QS Al - Baqarah : 170).

JAS: Volume 1 Nomor 1, 2019 
"Dan sesungguhnya Kami jadikan untuk isi neraka Jahanam kebanyakan dari Jin dan Manusia, mereka mempunyai hati, tetapi tidak dipergunakannya untuk memahami ayat-ayat Allah, dan mereka mempunyai mata tetapi tidak dipergunakannya untuk melihat tanda-tanda kekuasaan Allah dan mereka mempunyai telinga tetapi tidak dipergunakannya untuk mendengar ayat-ayat Allah. Mereka seperti hewan ternak, bahkan lebih sesat lagi. Mereka itulah orang-orang yang lengah". (QS. Al A'raf:179).

Kebebasan berpikir, menyatakan pendapat dan berbeda pendapat termasuk dalam kategori kebebasan yang universal. Islam mengakui dan melindungi prinsip ini. Kebebasan berpikir erat kaitannya dengan kebebasan untuk menentukan keyakinan dan agama yang dianut oleh seseorang. Ia termasuk dalam kebebasan hati nurani setiap manusia sejak dilahirkan secara naluriah memiliki kebebasan ini.

Kebebasan berpikir dan kebebasan menyatakan pendapat harus berdasarkan kepada tanggung jawab yang tidak boleh menganggu ketertiban umum atau menimbulkan suasana permusuhan di kalangan manusia sendiri. Dengan kata lain, kebebasan berpikir tidaklah berarti bahwa setiap orang bebas menghina, atau memperolok-olokkan orang lain atau keyakinan dan agama orang lain. Kebebasan berpikir dan kebebasan menyatakan pendapat dalam Islam haruslah dipahami dalam konotasi yang positif.

Kebebasan untuk berbeda pendapat juga merupakan hak seseorang dalam Islam. Hak tersebut dapat digunakan oleh setiap orang, misalnya dalam suatu forum musyawarah. Setiap orang bebas menyatakan pendapatnya, sekalipun berbeda dengan orang lain. Dalam ajaran Islam, perbedaan pendapat di kalangan umat Islam dipandang sebagai suatu rahmat. Hal ini ditegaskan dalam Hadits Nabi SAW : "Ikhtilafu ummati rahmah".

Kebebasan untuk berbeda pendapat dapat dipandang sebagai suatu yang telah pula melekat pada setiap pribadi manusia sesuai dengan fitrah atau watak aslinya.

\section{Kebebasan untuk Memiliki Harta Benda}

Islam tidak membedakan jenis kelamin, siapapun baik pria maupun wanita, anak-anak atau orang dewasa, mereka memiliki kebebasan untuk mempunyai harta benda. Pemilikan harta benda itu bersifat individual atau perorangan. Dalam Islam, Negara berkewajiban melindungi hak-hak kebendaan tersebut. Tiada seorang pun yang boleh merampas atau menguasai hak milik orang lain. Bahkan Negara pun dilarang untuk melakukan itu, kecuali dalam keadaan yang dibenarkan oleh hukum dan untuk kepentingan umum, Negara boleh menggunakan hak kebendaan milik seseorang dengan syarat seijin dan sepertujuan pemiliknya dan dengan diberikan ganti kerugian atas nilai bendanya dengan jumlah yang cukup atau sebagaimana layaknya JAS: Volume 1 Nomor 1, 2019 
menurut harga umum. Dalam keadaan tersebut, Negara dilarang memaksa atau merampas hak-hak warganya dengan cara kekerasan. Dalam ajaran Islam setiap pengambilalihan hak milik seseorang disertai dengan suatu kompensasi yang cukup adil.

Dalam hukum Islam, hak-hak atas benda berfungsi sosial dan diatur dengan konsep "amar ma'ruf nahi munkar". Si pemilik hak-hak tersebut berkewajiban memelihara harta bendanya dengan sebaik-baiknya dan menggunakannya untuk tujuan-tujuan yang dibenarkan oleh hukum Islam. Penggunaan hak-hak atas benda itu haruslah dapat menimbulkan kegunaan atau manfaat, baik bagi dirinya maupun bagi masyarakat. Harta benda yang dimiliki seseorang merupakan suatu amanah Tuhan yang wajib ia pelihara. Dari segi kepentingan sosial, si pemilik harta itu berkewajiban mengeluarkan sejumlah tertentu sebagai zakat hartanya. Sebagaimana bunyi firman Allah SWT :

"Ambillah zakat dari harta mereka, guna membersihkan dan menyucikan mereka...." (QS At Taubah : 103)

Kedudukan hak-hak atas benda dalam hukum Islam memberikan suatu keseimbangan antara kepentingan individual dan kepentingan sosial. Siapapun memiliki sesuatu benda akan memikul suatu kewajiban sosial. Setiap harta yang ia miliki bukan merupakan suatu kepemilikan yang bersifat individualistic dalam makna ia boleh memperdulikan masyarakat, tetapi suatu kepemilikan yang bersifat individulistik dalam makna ia boleh memperdulikan masyarakat, tetapi suatu kepemilikan mengandung dua dimensi sekaligus, baik individualistic maupun sosial. Dengan demikian hakhak atas benda dalam Islam, disamping menganugerahkan kewenangan juga meletakkan beban kewajiban kepada pemiliknya untuk memperhatikan kepentingan umum. Di lihat dari segi etik keagamaan, si pemilik harta kelak dituntut pertanggungjawabannya di hadapan Tuhan tentang darimana sumber harta itu dan ke mana ia telah gunakan .

Karena itu dalam hukum Islam setiap orang yang beriman dituntut untuk memperoleh harta dari sumber yang dibenarkan oleh hukum (halal) dan menggunakannya untuk hal-hal atau tujuan-tujuan yang dibenarkan oleh hukum pula.

Kebebasan untuk memiliki harta benda sangat erat hubungannya dengan kebebasan untuk berusaha dan memilih pekerjaan.

JAS: Volume 1 Nomor 1, 2019 
4. Kebebasan untuk berusaha dan memilih pekerjaan

Dalam Islam manusia dianugerahi kebebasan berusaha dan memilih pekerjaan yang legal dari segi hukum Islam. Berusaha dan bekerja bukan hanya sekedar hak atau kewenangan seseorang, tetapi ia merupakan perintah agama atau kewajiban, manusia diperintahkan untuk mengelola bumi dan sumber-sumber alam untuk kemakmuran manusia endiri. Tuhan telah menciptakan bumi dan sumber-sumber alam dengan cara sedemikian rupa sehingga melalui ilmu dan teknologi yang dimiliki manusia, bumi dan sumbersumber alam itu dapat dikelola dengan mudah. Salah satu ayat Al Qur'an yang memerintahkan manusia untuk memanfaatkan bumi dan sumber-sumber alam adalah sebagaimana yang tertera dalam QS Al Mulk : 15, yang artinya :

"Dialah yang menjadikan bumi itu secara yang dapat kamu gunakan dengan mudah, maka berjalanlah di segala penjurunya dan makanlah sebagian dari rejekiNya. Dan hanya kepadaNyalah kamu kembali setelah dibangkitkan."

Kebebasan berusaha dan memilih pekerjaan dalam Islam harus dilindungi oleh Negara, dan pemerintah berkewajiban memberikan kesempatan seluas-luasnya kepada setiap warganya untuk memilih usaha atau pekerjaan apa yang bermanfaat baginya.

\section{Prinsip Peradilan Bebas}

Dalam Islam, seseorang hakim memiliki kewenangan yang bebas dalam makna setiap putusan yang ia ambil bebas dari pengaruh siapapun. Hakim wajib menerapkan prinsip keadilan dan persamaan terhadap siapapun, sebagaimana firman Allah SAW :

“.... bila kamu menetapkan hukum diantara manusia maka hendaklah kamu tetapkan dengan adil”. (QS An-Nisa : 57)

Putusan hakim harus mencerminkan rasa keadilan hukum terhadap siapapun. Seorang yuris terkenal Abu Hanifah berpendapat bahwa kekuasaan kehakiman harus memiliki kebebasan dari segala macam bentuk tekanan dan campur tangan kekuasaan eksekutif, bahkan kebebasan tersebut mencakup pula wewenang hakim untuk menjatuhkan putusannya pada seorang penguasa apabila ia melanggar hak-hak rakyat.

Prinsip keadilan bebas dalam Islam bukan hanya sekedar ciri bagi suatu Negara hukum, tetapi juga ia merupakan suatu kewajiban yang harus dilaksanakan bagi setiap hakim. Peradilan bebas merupakan persyaratan bagi tegakya prinsip keadilan dan persamaan hukum. 
Prinsip peradilan bebas tidak boleh bertentangan dengan tujuan hukum Islam, yaitu memelihara agama, jiwa, akal, keturunan, dan harta. As Sunnah. Dalam melaksanakan prinsip peradilan bebas hakim wajib memperhatikan pula prinsip amanah, karena kekuasaan kehakiman yang berada di tangannya adalah pula suatu amanah dari rakyat kepadanya yang wajib ia pelihara dengan sebaik-baiknya. Sebelum ia menetapkan putusannya hakim wajib bermusyawarah dengan para koleganya agar dapat dicapai suatu putusan yang seadil-adilnya. Putusan yang adil merupakan tujuan utama dari kekuasaan kehakiman yang bebas.

\section{Prinsip Perdamaian (Al-Ishlah)}

Islam adalah agama perdamaian, oleh karena itu harus ditegakkan atas dasar prinsip perdamaian. Hubungan dengan Negara lain harus dijalin dan berpegang pada prinsip perdamaian. Pada dasarnya sikap bermusuhan atau perang merupakan sesuatu yang terlarang dalam Al-Qur'an, perang hanya merupakan tindakan darurat dan bersifat defensif atau membela diri. Al Qur'an hanya mengijinkan tindakan kekerasan atau perang apabila pihak lain memulai lebih dahulu melancarkan serangan. Al Qur'an mengatur hukum perang dan menggariskannya sebagai berikut :

"Dan terhadap orang yang menyerang kamu maka seranglah ia seperti ia menyerangmu". (QS Al - Baqarah : 194)

"Berperanglah demi Allah melawan orang-orang yang memerangi kamu, dan janganlah kamu memulai permusuhan. Sesungguhnya Allah tidak menyukai orang-orang yang memulai permusuhan". (QS Al Baqarah : 190)

Apabila tindakan kekerasan atau perang terpaksa dilakukan maka Nabi Muhammad SAW memberikan beberapa kaidah dalam hukum perang dengan menggunakan prinsip kewajaran dan kasih saying terhadap sesama manusia. Karena itu telah digariskan seperangkat larangan yang harus diindahkan oleh pasukan Islam, antara lain :

- Dilarang melakukan pembunuhan terhadap musuh secara kejam dan melampaui batas kemanusiaan.

- Dilarang membunuh penduduk sipil termasuk anak-anak, orang tua, orang cacat, biarawan, wanita, para pertapa, dan orang-orang sakit.

- Dilarang membunuh tawanan perang

- Dilarang memenggal kepala mayat musuh

- Dilarang membunuh musuh setelah musuh dikalahkan atau sesuatu daerah berhasil diduduki.

JAS: Volume 1 Nomor 1, 2019 
- Dilarang menyerang musuh yang berlidung di belakang wanita, anakanak, dan orang Islam yang dijadikan sandera.

- Dilarang menganiaya tawanan perang

- Dilarang merusak rumah-rumah atau tempat-tempat ibadah pihak musuh.

Semua aturan diatas pada hakikatnya adalah mengacu pada prinsip kesatuan umat manusia, meskipun manusia itu berbeda-beda suku bangsa, agama, warna kulit, bahkan tanah air, akan tetapi merupakan satu kesatuan manusia karena sama-sama makhluk Allah, sama-sama bertempat tinggal di bumi ini, sama-sama mengharapkan kehidupan yang bahagia dan damai, serta sama-sama dari Adam. Dengan demikian, maka perbedaan-perbedaan di antara manusia harus disikapi dengan pikiran yang positif untuk saling memberikan kelebihan masing-masing dan saling menutupi kekurangan masing-masing. Sebagaimana dinyatakan dalam Al Qur'an :

"Manusia adalah umat yang satu." (QS Al - Baqarah : 213). “Dan jika golongan itu telah kembali kepada perintah Allah, maka damaikanlah antara keduanya dengan adil, dan berlakulah adil, sungguh Allah mencintai orangorang yang berlaku adil". (QS Al-Hujurat : 9).

\section{Prinsip Kesejahteraan}

Prinsip kesejahteraan dalam Islam adalah bertujuan mewujudkan keadilan sosial bagi seluruh rakyat. Keadilan sosial dan ekonomi dimaksudkan untuk mencegah terjadinya penimbunan harta di tangan seseorang atau sekelompok orang. Sementara anggota masyarakat lainnya mengalami kemiskinan. Salah satu misi Islam ialah memerangi kemiskinan, sekurangnya menghilangkan kesenjangan (disparitas) yang semakin melebar antara si kaya dan si miskin tersebut. Sebagaimana bunyi firman Allah SWT :

“.... agar harta itu jangan hanya beredar diantara orang-orang kaya saja di antara kamu." (QS Al - Hasyr : 7).

Untuk mewujudkan prinsip kesejahteraan ini, yang didalam Al Qur'an dirumuskan dengan kata-kata "baldatun thayibatun wa rabbun ghafur". Yang artinya "Inilah Negara yang makmur dan Tuhan Maha Pengampun" (QS Saba : 15). Yaitu suatu Negara yang sejahtera dibawah ridha Allah, dimana Negara berkewajiban mengatur dan mengalokasikan dana dalam jumlah yang cukup untuk keperluan jaminan sosial bagi mereka yang memerlukannya. Jaminan sosial itu mencakup, misalnya : tunjangan beasiswa pendidikan, tunjangan kesehatan, tunjangan orang tua usia lanjut, tunjangan bagi pemuda usia produktif yang masih pengangguran untuk diberi modal usaha dan lain-lain. 
Disamping itu Negara juga berkewajiban menyediakan sarana-sarana peribadatan, pendidikan, panti asuhan, rumah sakit, dan lain-lain.

\section{A. SIMPULAN}

Islam tidak mengkonsep kan negara kepada bentuk tertentu, melainkan dasar dasar yang harus dijalankan diharuskan oleh agama Islam. Dalam Islam, hukum adalah "titah" Allah yang berkaitan dengan perbuatan orang dewasa (mukallaf) yang berisi perintah dan larangan serta janji dan ancaman, dimana penguasa yang diberi amanah untuk menegakkan hukum ini harus melaksanakan dengan penuh tanggung jawab dan akan dimintai pertanggungjawaban di akhirat kelak. Penguasa yang amanah akan mendapatkan "rahmat", sebaliknya penguasa yang khianat akan mendapatkan "Laknat". Dalam perspektif Islam, sistem dan bentuk Negara bisa bermacam-macam dan berbeda-beda, tetapi maksud dan tujuan pembentukan Negara adalah sama, yaitu terwujudnya Negara dan pemerintahan yang adil, damai, dan sejahtera (Darussalam). Hal ini bisa kita lihat dalam Negara dan pemerintahan di Madinah yang dipimpin oleh Muhammad Rasulullah SAW. Untuk mewujudkan cita-cita Negara "Darussalam" tersebut, maka dibuatlah sistem dan tata kelola Negara hukum yang didasarkan pada Nash Al Qur'an, As - Sunnah, atau dengan cara ijtihad, apabila kemaslahatan umum mengharuskan demikian, sebagaimana yang dijelaskan dalam kaidah hukum Islam (Qaidah Fiqhiyah) :"Tasharuf (tindakan) Imam terhadap rakyat harus dihubungkan dengan kemaslahatan".

\section{DAFTAR PUSTAKA}

A. Ubaidillah dan Abdul Rozak, (2006). Demokrasi Hak Asasi Manusia, dan Masyarakat Madani, ICCE UIN Syarif Hidayatullah, Jakarta.

M. Natsir (2001). Agama dan NegaraDalam Perspektif Islam, Media Da'wah, Jakarta.

JAS: Volume 1 Nomor 1, 2019 